\title{
VERIFIKASI TANDA TANGAN MENGGUNAKAN EKSTRAKSI FITUR LBP DAN DCT DENGAN KLASIFIKASI LVQ
}

\author{
(Signature Verification Using Feature of LBP and DCT With LVQ Classifier)
}

\author{
Medeline Widia Andani ${ }^{*}$, Gibran Satya Nugraha \\ Program Studi Teknik Informatika, Fakultas Teknik, Universitas Mataram \\ JI. Majapahit 62, Mataram, Lombok NTB, INDONESIA \\ Email: medelinewidiaa@gmail.com, gibransn@unram.ac.id
}

\begin{abstract}
Signature is one of the media used for verification and legalization of information, such as documents that are closely related to legality. In general, signature verification is done manually by direct comparing, this is certainly not effective, especially if doing a lot verification. Therefore, we need a computer system that can automatically verify a person's signature to save time in matching and reducing errors. This research was conducted using combination feature of Local Binary Pattern (LBP) and Discrete Cosine Transform (DCT) to obtain parameters values that will be used as input to classification. Then, Learning Vector Quantization (LVQ) algorithm is used as classifier to identify and verification features of the signature. The Datasets that used in this research are 600 signature images with a size of $500 \times 500$ pixels taken from 30 respondents where each respondent taken 15 original signatures and 5 fake signatures. The results of this research are that the signature identification process resulted in $93 \%$ and the verification process resulted in an accuracy of $63 \%$, a sensitivity of $89 \%$, and a specificity of $42 \%$.
\end{abstract}

Keywords: signature, verification, LBP, DCT, LVQ

*Penulis Korespondensi

\section{Pendahuluan}

Pada perkembangan teknologi yang cukup pesat ini keamanan menjadi kebutuhan manusia yang tidak bisa dilepaskan. Baik keamanan untuk dirinya sendiri maupun keamanan hal-hal yang berkaitan dengan dirinya, seperti dokumen-dokumen legal dan penting. Salah satu pengaman yang terkenal adalah dengan tanda tangan. Tanda tangan dianggap lebih mudah digunakan, murah, dan cukup efektif[1].

Verifikasi tanda tangan (signature verification) meliputi dua bagian yang berbeda tetapi berkaitan erat satu sama lain. Yang pertama adalah identifikasi dari pemilik tanda tangan sedangkan yang kedua adalah keputusan apakah tanda tangan tersebut asli atau dipalsukan[2]. Secara umum, verifikasi tanda tangan dilakukan dengan cara manual, yaitu dengan membandingkan secara langsung dengan mata manusia. Cara ini mempunyai banyak kelemahan yaitu penglihatan menjadi letih, terutama jika melakukan cukup banyak verifikasi, dapat menyebabkan kebosanan orang yang melakukannya, sehingga ketelitian dan ketepatan hasil yang diinginkan seringkali kurang memuaskan[3]. Oleh karena itu, dibutuhkan suatu sistem komputer yang otomatis dapat memverifikasi tanda tangan seseorang untuk menghemat waktu dalam pencocokan dan mengurangi kesalahan. Namun, komputer tidak dapat langsung melakukan verifikasi tanda tangan, sehingga dibutuhkan proses pengenalan pola terlebih dahulu dengan melakukan ekstraksi fitur pada citra tanda tangan dimana fitur tersebut akan diklasifikasi sehingga citra tanda tangan dapat dikenali.

Terdapat berbagai metode yang dapat digunakan untuk melakukan ekstraksi fitur pada citra, Salah satunya yaitu Local Binary Pattern (LBP). LBP merupakan suatu metode yang digunakan untuk mencari pola-pola tekstur lokal pada citra. Metode LBP teruji ampuh untuk mendeskripsikan tekstur karena memiliki daya pembeda yang akurat, mudah diimplementasikan dan merupakan metode ekstraksi fitur yang cukup cepat dengan proses komputasi yang rendah[4].

Kemudian, terdapat metode Discrete Cosine Transform (DCT). Metode DCT merupakan sebuah teknik yang mengubah sinyal ke dalam bentuk frekuensi dasar. DCT dipilih karena memiliki kemampuan yang baik untuk mengumpulkan informasi fitur penting pada frekuensi rendahnya dan fitur pada gambar tersebut dapat memberikan informasi mengenai fitur dengan kolerasi yang tinggi. DCT tidak berkorelasi dengan indeks frekuensi lawannya sehingga jika sebagian komponen non-dominan 
dihapus maka tidak akan secara signifikan mengurangi kualitas informasinya[5]. Sehingga DCT merupakan metode yang cocok digunakan dilihat dari dataset tanda tangan yang memiliki lebih banyak jumlah background dibandingkan dengan tulisan tanda tangan yang dibutuhkan.

Pada tahap klasifikasi, salah satu metode yang dapat digunakan yaitu metode Learning Vektor Quantization (LVQ). LVQ adalah suatu metode untuk melakukan pembelajaran pada lapisan kompetitif yang terawasi. Suatu lapisan kompetitif akan secara otomatis belajar untuk mengklasifikasikan vektorvektor input. Jika dua vektor input mendekati sama, maka lapisan kompetitif akan meletakkan kedua vektor input tersebut ke dalam kelas yang sama. Keunggulan metode LVQ adalah kemampuannya untuk memberikan pelatihan terhadap lapisan-lapisan kompetitif sehingga secara otomatis dapat mengklasifikasikan vektor input yang diberikan[6] dan menghasilkan error yang lebih kecil serta waktu yang lebih cepat dibandingkan dengan backpropogation[7].

Berdasarkan uraian di atas, penulis melakukan penelitian untuk perancangan sebuah model verifikasi tanda tangan menggunakan fitur LBP dan teknik klasifikasi dengan metode LVQ. Luaran dari penelitian ini diharapkan sistem dapat melakukan verifikasi tanda tangan dengan baik.

\section{TinjauAn PUStaka}

Penelitian mengenai verifikasi tanda tangan, ekstraksi fitur LBP dan klasifikasi LVQ sudah pernah dilakukan. Perbedaan paling menonjol dari setiap penelitian terletak pada dataset dan fitur-fitur yang digunakan. Penelitian - penelitian yang dimaksud antara lain verifikasi tanda tangan menggunakan ekstraksi fitur Edge Detection dengan metode prewitt dan klasifikasi dengan metode LVQ dimana dataset berjumlah 400 yaitu 300 tanda tangan asli dan 100 tanda tangan palsu dimana dataset diambil dengan kertas dan akurasi yang diperoleh sebesar 70\%.[3]. Pada penelitian verifikasi tanda tangan berdasarkan sifat keacakan (entropi), terdapat 30 responden dimana setiap responden diambil 30 tanda tangan asli dan 5 tanda tangan palsu dimana dataset diambil dengan kertas. Penelitian ini menghasilkan akurasi sebesar 96,67\%[8].

Ekstraksi ciri menggunakan metode LBP telah dilakukan antara lain untuk identifikasi ciri telapak tangan dimana metode KNN digunakan untuk klasifikasi. Data yang digunakan berjumlah 78 dan hasil terbaik dari metode LBP terdapat pada parameter jarak tetangga $(R)=2$, jumlah tetangga $(P)=8$, akurasi mencapai $92,31 \%[9]$. Pada penelitian tentang analisis citra daun digunakan 10 fitur LBP dengan klasifikasi KNN, akurasi tertinggi diperoleh 94.28\%[10]. Dan metode LBP juga digunakan untuk mengidentifikasi cacat kayu dimana akurasi tertinggi mencapai $89 \%$ dengan menggunakan pola ketetanggaan LBP yaitu $[4,1][11]$.

Ekstraksi fitur dengan metode DCT juga telah dilakukan antara lain untuk mengidentifikasi daun tembakau dimana dataset yang digunakan berjumlah 40 citra dengan 30 citra sebagai data latih dan 10 citra sebagai data uji. Metode klasifikasi yang digunakan yaitu backpropogation. Penelitian ini menghasilkan akurasi sebesar $90 \%[12]$. selain itu, metode DCT juga digunakan untuk pengenalan iris dimana dataset yang digunakan berjumlah 420 citra. Metode klasifikasi yang digunakan yaitu KNN. pada penelitian ini, akurasi tertinggi yaitu $71,67 \%[13]$.

Teknik klasifikasi menggunakan metode LVQ juga telah dilakukan antara lain penelitian tentang identifikasi kesegaran susu sapi dengan ekstraksi fitur metode watershed. Pada penelitian ini digunakan 120 data dengan 3 kelas. data uji terdiri dari 10 citra susu pada setiap kelasnya, akurasi yang dihasilkan yaitu 92,5\%[14]. Serta penelitian mengenai klasifikasi citra daging sapi dan daging babi. akurasi tertinggi dengan menggunakan MaxEpoch 100, a sebesar 0.01[15].

Penelitian tentang pengenalan citra menggunakan kombinasi metode LBP dan klasifikasi LVQ sebelumnya sudah pernah dilakukan yaitu mengenai identifikasi sub-fosil gigi geraham pada manusia dengan 270 dataset gigi geraham untuk rentang umur kematian dari sub-fosil manusia, dan 250 dataset gigi graham manusia. Dalam mengidentifikasi jenis gigi geraham pada manusia didapatkan akurasi sebesar $81,81 \%$ dan akurasi sebesar $77,69 \%$ dalam mengidentifikasi rentang umur kematian dari sub-fosil manusia[16]. Penelitian tentang pengenalan citra menggunakan metode ekstraksi fitur DCT dan klasifikasi LVQ juga sudah pernah dilakukan yaitu penelitian mengenai deteksi kanker serviks dimana dataset yang digunakan berjumlah 73. Proses pengujian LVQ menggunakan 15 buah citra sel normal dan 9 buah citra sel kanker. Dari hasil pengujian, didapatkan nilai sensitivitas, spesifisitas, dan akurasi sebesar $88,89 \%, 100 \%$, dan 95,83\%[17].

Berdasarkan penelitian-penelitian tersebut, dapat diketahui bahwa metode ekstraksi fitur LBP dan DCT serta klasifikasi menggunakan metode LVQ dapat bekerja dengan baik untuk pengklasifikasian citra. Oleh karena itu, penulis bermaksud menggunakan metode ini untuk melakukan verifikasi citra tanda tangan. 


\section{Metode Penelitian}

\subsection{Diagram Alir Penelitian}

Terdapat beberapa tahapan yang dilakukan dalam penelitian ini, tahap pertama dilakukan studi literatur untuk menambah wawasan penulis mengenai apa yang akan dilakukan. Studi literatur ini dilakukan melalui referensi-referensi yang berasal dari jurnal, buku, dan penelitian-penelitian yang pernah dilakukan sebelumnya. Selanjutnya, dilakukan pengumpulan dataset yang akan digunakan sebagai data latih dan data uji. Setelah dataset berhasil dikumpulkan maka penelitian akan diteruskan dengan membangun model menggunakan metode ekstraksi fitur LBP dan DCT serta klasifikasi LVQ. Hasil dari model ini akan menjadi bahan analisis untuk mengetahui performa dari model yang dibangun. Jika model masih memiliki akurasi yang kurang memuaskan maka penelitian akan diulang kembali dari tahap studi literatur. Jika sudah mendapat hasil sesuai maka akan diambil kesimpulan mengenai performa dari model. Terakhir, dilakukan penyelesaian dokumentasi penelitian dalam bentuk laporan akhir. Diagram alir penelitian dapat dilihat pada Gambar 1.

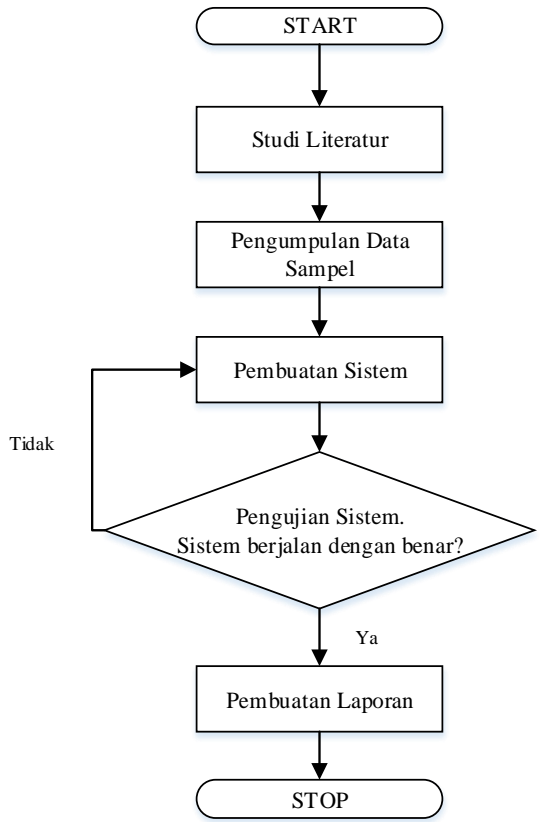

Gambar 1. Diagram alir proses penelitian

\subsection{Persiapan Dataset}

Pada penelitian ini, pembuatan model machine learning menggunakan dataset keseluruhan berjumlah 600 citra tanda tangan yang diambil dari 30 mahasiswa Teknik Informatika Universitas Mataram secara acak sehingga dataset terdiri dari 30 kelas. Dataset terdiri dari 450 tanda tangan asli dan 150 tanda tangan palsu. Tanda tangan asli diambil pada tiga hari yang berbeda dengan tujuan untuk menambah variasi tanda tangan, setiap 1 hari diambil 5 tanda tangan asli sehingga setiap kelas terdiri dari 15 citra tanda tangan. Tanda tangan palsu terdiri dari 5 tanda tangan setiap kelas yang dikerjakan oleh 5 orang yang dipercaya peneliti dapat meniru tanda tangan. Dataset tersebut diambil menggunakan smartphone Samsung Galaxy Tab A dengan menggunakan aplikasi IbisPaintX.

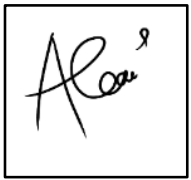

(a)

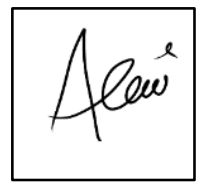

(b)
Gambar 2. Dataset tanda tangan (a) asli dan (b) palsu

\subsection{Sistem verifikasi Tanda Tangan}

Terdapat dua proses utama dalam penelitian ini, yaitu proses pelatihan dan proses pengujian. Preprocessing dan ekstraksi fitur yang dilakukan pada proses pelatihan dan proses pengujian sama.

Pada proses pelatihan dan proses pengujian dilakukan input ke dalam sistem yaitu citra hitam putih dan berukuran $500 \times 500$. pada tahap preprocessing dilakukan proses manipulasi gambar sesuai dengan yang ditentukan dengan melakukan resize. Selanjutnya, dilakukan ekstraksi fitur pada penelitian ini menggunakan metode LBP. Hasil dari proses LBP tersebut kemudian diolah dengan metode DCT. Metode DCT digunakan untuk mengambil fitur penting atau fitur terbaik dengan memilih komponen-komponen dominan pada citra hasil ekstraksi fitur LBP, sehingga hasil dari proses DCT yang akan diklasifikasikan.

Proses pelatihan menggunakan klasifikasi LVQ dengan nilai maximal Epoch, dan learning rate. Sedangkan pada proses pengujian, pelatihan metode LVQ menggunakan bobot akhir dari hasil proses pelatihan. kemudian dilanjutkan dengan tahap verifikasi dengan menghitung similarity antara fiturfitur citra latih dengan jumlah rata-rata setiap fitur citra pada kelasnya. Citra tanda tangan asli atau palsu ditentukan berdasarkan nilai variabel threshold yang ditentukan pada saat penelitian dilakukan. Perancangan sistem dapat dilihat pada Gambar 3.

\subsubsection{Preprocessing}

Pengolahan awal (preprocessing) bertujuan untuk mengelola citra agar dapat diperoleh informasi dari suatu citra secara optimal, tahap pengolahan awal citra dalam penelitian ini adalah melakukan resize. Pada tahap resize, dilakukan pengubahan ukuran citra agar setiap input citra memiliki resolusi yang sama[18].

\subsubsection{Ekstraksi fitur LBP}

Algoritma LBP adalah suatu metode yang digunakan untuk mendeskripsikan ciri tekstur pada objek citra grayscale. LBP digunakan untuk mencari 
pola-pola tekstur lokal pada citra (texture in local neighborhood)[19].

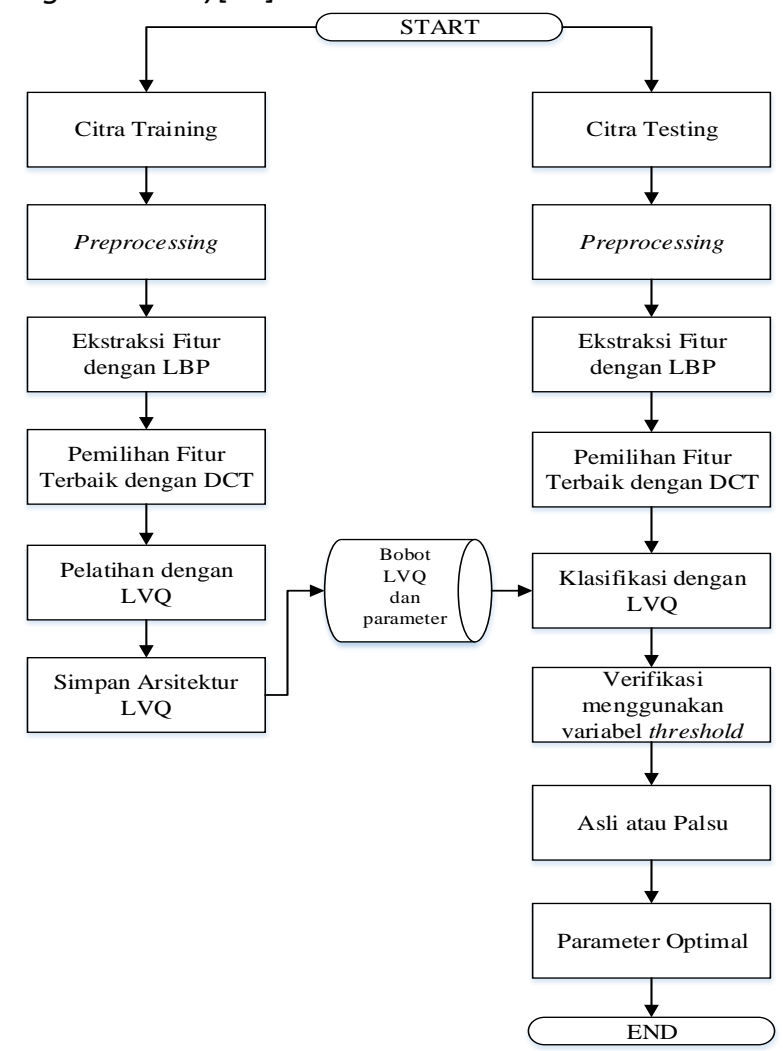

Gambar 3. Diagram alir sistem verifikasi tanda tangan

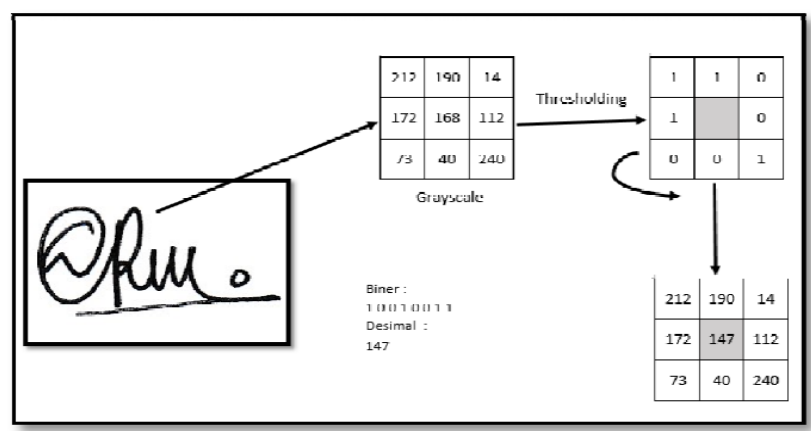

Gambar 4. Ilustrasi LBP[19]

Gambar 4 merupakan ilustrasi dari proses ekstraksi fitur LBP. Proses pertama adalah piksel ketetanggaan di-threshold menggunakan nilai keabuan dari piksel tengah sebagai fungsi thresholding jika hasilnya lebih besar atau sama dengan 0 maka diberi nilai 1 dan jika hasilnya kurang dari 0 maka diberi 0 . Setelah itu, nilai biner piksel ketetanggaan akan disusun berlawanan arah jarum jam dan 8 bit biner tersebut dikonversi ke dalam nilai desimal untuk menggantikan nilai piksel tengah[19].

\subsubsection{Pemilihan Fitur Terbaik dengan DCT}

DCT telah banyak digunakan dalam literatur untuk efisiensi pemilihan fitur tekstur. DCT menggunakan cosinus dari berbagai frekuensi spasial sebagai fungsi dasar dan umumnya dikenal karena penerapannya dalam standar kompresi JPEG. Untuk tekstur citra, sebagian besar energi sinyal terletak pada komponen frekuensi rendah, yang mana muncul di sudut kiri atas DCT.

Penelitian ini mengekstraksi fitur tekstur dengan mengaplikasikan DCT dimana derajat keabuan setiap piksel dalam citra hasil ekstraksi LBP dinormalisasi menjadi 128 melalui operasi substraction. Kemudian, citra dibagi menjadi $8 \times 8$ blok, dan setiap blok diproses dengan operasi 2DDCT seperti pada persamaan (1)[12].

$C(u, v)=$

$$
a(u) a(v) \sum_{x=0}^{N-1} \sum_{y=0}^{N-1} f(x, y) \cos \left[\frac{(2 x+1) \pi \mu}{2 N}\right] \cos \left[\frac{(2 y+1) \pi \mu}{2 N}\right]
$$

Selama proses DCT berlangsung, dihitung pula invers dari 2D-DCT dengan menggunakan persamaan (2).

$f(x, y)=\sum_{x=0}^{N-1} \sum_{y=0}^{N-1} f(x, y) \cos \left[\frac{(2 x+1) \pi \mu}{2 N}\right] \cos \left[\frac{(2 y+1) \pi \mu}{2 N}\right]$

Matriks hasil transformasi DCT yang telah terisi dengan koefisien DCT selanjutnya diproses pada tahap kuantisasi, dimana data yang terletak pada kiri atas merupakan korelasi dari frekuensi-frekuensi rendah dari data asli. Sedangkan yang terletak pada kanan bawah merupakan korelasi dari frekuensifrekuensi tinggi dari data asli.

Pada tahap kuantitasi, digunakan algoritma Huffman yaitu dengan Menyusun bilangan menggunakan fungsi zigzag scanning[20]. Proses ini bertujuan untuk menentukan fitur terbaik dari citra yang selanjutnya akan diproses pada tahap klasifikasi, dimana jumlah fitur yang diambil sejumlah nilai koefisien yang digunakan.

\subsubsection{Klasifikasi LVQ}

LVQ merupakan jaringan syaraf dengan tipe arsitektur jaringan lapis-tunggal umpan-maju (Single Layer Feedforward) yang terdiri atas unit masukan dan unit keluaran. Jika 2 vektor masukan mendekati sama, maka lapisan kompetitif akan meletakkan kedua vektor masukan tersebut ke dalam kelas yang sama[21]. Arsitektur jaringan LVQ seperti terlihat pada Gambar 5.

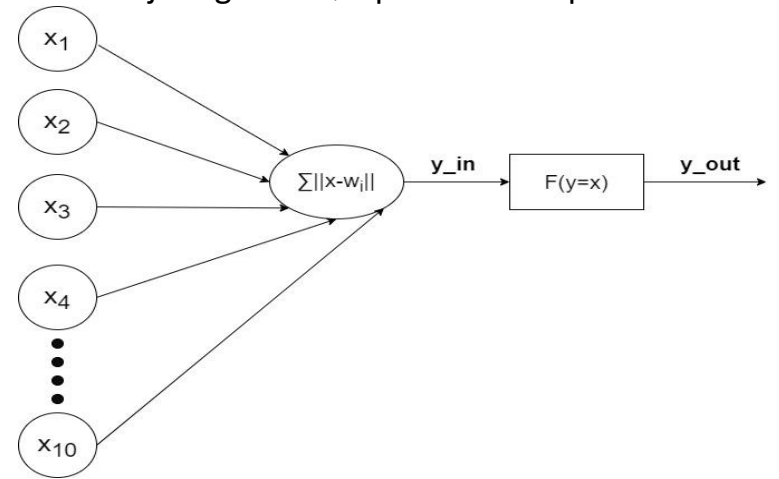

Gambar 5. Arsitektur LVQ 
Gambar 5 memperlihatkan bahwa yang bertindak sebagai dendrit atau data masukan adalah $X_{1}-X_{10}$, yang bertindak sebagai sinapsis atau bobot adalah $W$, sedangkan soma atau badan sel dari jaringan ini adalah perhitungan $X-W$. Dan yang bertindak sebagai akson atau data keluaran adalah $Y_{-}$out. Algoritma LVQ adalah sebagai berikut[22]:

a. Tentukan MaxEpoch (banyaknya proses pelatihan yang akan diulangi), eps (error minimum yang diharapkan) dan nilai alpha.

b. Hasil ekstraksi ciri pertama dari masing-masing pola digunakan sebagai data awal (inisialisasi). Data inisialisasi ini akan diisi sebagai nilai bobot awal $(w)$.

c. Epoch $=0$

d. Selama (Epoch < MaxEpoch) atau (alpha > eps), maka lakukan hal berikut:

1. Epoch $=$ Epoch+1

2. Untuk setiap data hasil ekstraksi ciri, lakukan hal berikut:

- Set $x=$ hasil ekstraksi ciri dari pola.

- Set $T=$ nomor urut dari setiap kelas

- Hitung jarak hasil ekstraksi ciri pola saat ini dengan masing-masing bobot. Misalkan dihitung jarak hasil ekstraksi ciri pola pertama dengan setiap bobot dapat menggunakan persamaan (3).

$J=\sqrt{\left(x_{11}-w_{11}\right)^{2}+\cdots+\left(x_{1 m}-w_{1 m}\right)^{2}}$

Dengan:

$x_{1 m}=$ bit ekstraksi ciri dari pola-1 yang ke-m.

$W_{1 m}=$ bobot $W_{(1, m)}$

$m$ = banyak bit ekstraksi ciri

- Bila nomor kelas pada bobot yang memiliki jarak terkecil sama dengan nilai nomor urut (T) pola, maka hitung:

$$
W_{j}(\text { baru })=W_{j}(\text { lama })+\alpha\left(x-W_{j}(\text { lama })\right)
$$

- Bila tidak, maka hitung:

$$
W_{j}(\text { baru })=W_{j}(\text { lama })-\alpha\left(x-W_{j}(\text { lama })\right)
$$

3. kurangi nilai $\alpha$.

$$
\alpha=\alpha-\left(0.1^{*} \alpha\right)
$$

\subsubsection{Proses Verifikasi Tanda Tangan}

Pada proses pengujian, verifikasi tanda tangan dilakukan setelah sistem melakukan pengenalan tanda tangan. Verifikasi digunakan untuk membedakan tanda tangan asli dan tanda tangan palsu. Pada penelitian ini, digunakan rumus Euclidean Distance untuk menghitung kemiripan atau similarity data uji dengan nilai rata-rata fitur kelasnya. Pada penelitian sebelumnya, teknik Euclidean Distance menghasilkan akurasi lebih baik dibandingkan teknik Canberra distance[23], Minkwoski Distance dan Manhattan Distance[24] dalam menghitung kemiripan dua vektor. Rumus Euclidean Distance setiap index vektor dapat dihitung dengan persamaan (7) dimana pada penelitian ini, $x$ merupakan index vektor data yang diuji dan $y$ merupakan vektor nilai rata-rata fitur kelasnya yang telah diprediksi pada proses klasifikasi. Hasil dari Euclidean distance akan ditampung pada array.

$$
d(x, y)=\sqrt{\left(x_{i}-y_{i}\right)^{2}}
$$

Setelah itu, dilakukan normalisasi terhadap setiap index array. Persamaan (8) digunakan untuk melakukan normalisasi terhadap setiap index array, dimana $x$ merupakan nilai index array, nilai $_{\text {min }}$ merupakan nilai terkecil dari semua index pada array, dan nilai $_{\max }$ merupakan nilai terkecil dari semua index pada array.

$$
x^{\prime}=\frac{x-\text { nilai }_{\text {min }}}{\text { nilai }_{\text {max }}-\text { nilai }_{\text {min }}}
$$

Setelah dilakukan normalisasi, maka dicari nilai rata-rata array dengan menggunakan persamaan (9) Tanda tangan asli dan palsu ditentukan berdasarkan batas rentang nilai variabel threshold.

$$
x=\frac{\sum_{0}^{n} x_{i}}{n}
$$

\section{Hasil dan PEMBahasan}

\subsection{Skenario Pengujian}

Evaluasi hasil klasifikasi dapat dilakukan dengan menghitung nilai True Positive, True Negative, False Positive dan False Negative. Keempat nilai ini dapat dihitung berdasarkan confusion matrix seperti yang tertera pada Tabel I[25]. Nilai- nilai yang didapatkan dari confusion matrix kemudian akan digunakan untuk menghitung parameter-parameter evaluasi hasil klasifikasi.

TABEL I. CONFUSION MATRIX

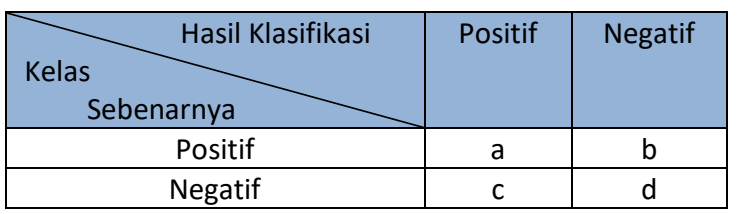

accuracy merupakan proporsi dari kedua kelas (positif dan negatif) dari total kelas yang diuji. Persamaan (10) menunjukkan perhitungan untuk nilai akurasi.

$$
\text { accuracy }=\frac{a+d}{a+b+c+d}
$$

True Positive Rate (recall) merupakan proporsi dari kelas positif yang diklasifikasikan dengan benar. Persamaan (11) menunjukkan perhitungan untuk nilai True Positive Rate.

$$
\text { True Positive Rate (recall) }=\frac{a}{a+b}
$$

True Negative Rate (specificity) merupakan proporsi dari kelas negatif yang diklasifikasikan dengan benar. Persamaan (12) menunjukkan perhitungan untuk nilai True Negative Rate. 


$$
\text { True Negative Rate (specificity) }=\frac{d}{c+d}
$$

\subsection{Performa Model Terbaik}

Pada tahap klasifikasi, dataset yang digunakan adalah dataset tanda tangan asli untuk proses training dan testing dengan jumlah 450 citra tanda tangan dengan 330 citra dijadikan data training dan 120 citra dijadikan data testing. Pada tahap verifikasi, dataset 150 tanda tangan palsu ditambahkan untuk menguji ketepatan dalam tahap verifikasi. Teknik pengujian yang digunakan untuk mengetahui performa model adalah k-fold cross validation. Cross validation merupakan metode statistik untuk mengevaluasi serta membandingkan algoritme learning dengan membagi data menjadi dua segmen, satu segmen digunakan untuk melatih model dan yang lain digunakan untuk memvalidasi model. Cross Validation bertujuan untuk menghindari tumpang tindih pada data testing[13]. Pada pengujian ini, digunakan 5 -fold cross validation.

Variabel-variabel uji yang digunakan adalah jumlah tetangga dan radius pada metode LBP, jumlah epoch dan learning rate pada metode LVQ, ukuran citra masukan serta variabel threshold. Berikut singkatan yang digunakan:

$\mathrm{P}=$ Jumlah Tetangga LBP

$\mathrm{R}=$ radius $\mathrm{LBP}$

acc $=$ accuracy

sen $=$ sensitivity

spe = specificity

$\mathrm{LR}=$ learning rate

\subsubsection{Pengujian Metode DCT}

Metode DCT digunakan untuk mengambil fitur penting atau fitur terbaik dengan memilih komponenkomponen dominan pada citra hasil ekstraksi fitur LBP, sehingga hasil dari proses DCT yang akan diklasifikasikan.

Untuk mencari model terbaik pada DCT dilakukan pengujian terhadap nilai koefisien DCT. Pemilihan koefisien pada penelitian ini yaitu dengan rentang 32128. Tabel II menunjukkan hasil pengujian koefisien DCT.

TABEL II. HASIL PENGUJIAN KoefisIEn DCT

\begin{tabular}{|l|c|c|}
\hline Koefisien & Akurasi Training & Akurasi Testing \\
\hline 32 & $93 \%$ & $91 \%$ \\
\hline 48 & $97 \%$ & $93,3 \%$ \\
\hline 64 & $96 \%$ & $92,6 \%$ \\
\hline 80 & $95 \%$ & $92,6 \%$ \\
\hline 96 & $96 \%$ & $92 \%$ \\
\hline 112 & $94 \%$ & $90 \%$ \\
\hline 128 & $94 \%$ & $90 \%$ \\
\hline
\end{tabular}

Berdasarkan Tabel II diketahui bahwa akurasi terbaik diperoleh pada koefisien DCT 48 dengan akurasi training yaitu 93,3\% dan akurasi testing dengan akurasi tertinggi yaitu $97 \%$.

\subsubsection{Pengujian Metode LBP}

Pengujian ini dilakukan untuk mencari parameter terbaik pada metode ekstraksi fitur LBP dalam mengidentifikasi dan memverifikasi tanda tangan dengan menguji jumlah tetangga dan radius LBP.

TABEL III. HASIL PENGUJIAN PARAMETER LBP

\begin{tabular}{|c|c|c|c|c|c|c|c|}
\hline \multicolumn{2}{|c|}{ Parameter } & \multicolumn{2}{|c|}{$\begin{array}{l}\text { Klasifikasi } \\
\text { (acc) }\end{array}$} & \multicolumn{3}{|c|}{ Verifikasi } & \multirow[t]{2}{*}{ Time } \\
\hline $\mathbf{P}$ & $\mathbf{R}$ & Train & Test & acc & sen & spe & \\
\hline 4 & 1 & $95 \%$ & $93 \%$ & $57 \%$ & $71 \%$ & $46 \%$ & $23 \mathrm{~s}$ \\
\hline 8 & 2 & $95 \%$ & $93 \%$ & $52 \%$ & $46 \%$ & $57 \%$ & $24 \mathrm{~s}$ \\
\hline
\end{tabular}

Berdasarkan Tabel III diketahui bahwa akurasi training dan akurasi testing kedua uji menghasilkan akurasi yang sama. Pada proses verifikasi, akurasi paling optimal yaitu pada $\mathrm{R}=1$ dan $\mathrm{P}=4$ dengan akurasi sebesar $57 \%$, sensitivity sebesar $71 \%$ dan specificity sebesar $46 \%$ dan waktu komputasi yang lebih cepat.

\subsubsection{Pengujian Metode LVQ}

Pengujian ini dilakukan untuk mencari parameter terbaik pada classifier LVQ dalam mengidentifikasi dan memverifikasi tanda tangan. dengan menguji Learning Rate dan Epoch pada parameter LVQ.

TABEL IV. HASIL PENGUJIAN PARAMETER LVQ

Pada Tabel VII diketahui bahwa pada proses

\begin{tabular}{|c|c|c|c|c|c|c|c|}
\hline \multicolumn{2}{|c|}{ Parameter } & $\begin{array}{c}\text { Klasifikasi } \\
\text { (acc) }\end{array}$ & \multicolumn{2}{c|}{ Verifikasi } & \multirow{2}{*}{ Time } \\
\hline LR & Epoch & Train & Test & acc & sen & spe & \\
\hline \multirow{4}{*}{0,001} & 50 & $86 \%$ & $84 \%$ & $57 \%$ & $69 \%$ & $48 \%$ & $22 \mathrm{~s}$ \\
\cline { 2 - 7 } & 100 & $89 \%$ & $88 \%$ & $57 \%$ & $70 \%$ & $46 \%$ & $23 \mathrm{~s}$ \\
\cline { 2 - 8 } & 150 & $93 \%$ & $91 \%$ & $58 \%$ & $70 \%$ & $48 \%$ & $24 \mathrm{~s}$ \\
\cline { 2 - 8 } & 200 & $92 \%$ & $90 \%$ & $56 \%$ & $70 \%$ & $45 \%$ & $25 \mathrm{~s}$ \\
\hline \multirow{5}{*}{0,01} & 50 & $96 \%$ & $93 \%$ & $57 \%$ & $71 \%$ & $46 \%$ & $22 \mathrm{~s}$ \\
\cline { 2 - 7 } & 100 & $94 \%$ & $92 \%$ & $57 \%$ & $70 \%$ & $47 \%$ & $23 \mathrm{~s}$ \\
\cline { 2 - 7 } & 150 & $96 \%$ & $93 \%$ & $58 \%$ & $70 \%$ & $47 \%$ & $25 \mathrm{~s}$ \\
\cline { 2 - 7 } & 200 & $95 \%$ & $93 \%$ & $57 \%$ & $71 \%$ & $47 \%$ & $26 \mathrm{~s}$ \\
\hline \multirow{5}{*}{0,1} & 50 & $95 \%$ & $92 \%$ & $58 \%$ & $71 \%$ & $47 \%$ & $22 \mathrm{~s}$ \\
\cline { 2 - 7 } & 100 & $95 \%$ & $92 \%$ & $58 \%$ & $71 \%$ & $47 \%$ & $23 \mathrm{~s}$ \\
\cline { 2 - 7 } & 150 & $94 \%$ & $92 \%$ & $57 \%$ & $71 \%$ & $46 \%$ & $24 \mathrm{~s}$ \\
\cline { 2 - 6 } & 200 & $95 \%$ & $93 \%$ & $58 \%$ & $72 \%$ & $47 \%$ & $25 \mathrm{~s}$ \\
\hline
\end{tabular}

klasifikasi hasil akurasi testing tertinggi yaitu 93\%. Pada proses verifikasi, ketiga jenis evaluasi hasil yaitu accuracy, sensitivity dan specificity di rata-ratakan untuk mendapatkan evaluasi hasil paling optimal. Sehingga, hasil evaluasi paling optimal untuk proses klasifikasi yaitu pada $L R=0,1$ dengan epoch $=100$ dimana akurasi testing yaitu 93\%, hasil accuracy sebesar $58 \%$, sensitivity sebesar $72 \%$ dan specificity sebesar $47 \%$. Waktu komputasi pada setiap parameter uji tidak memiliki perbedaan yang signifikan. 


\subsubsection{Pengujian Ukuran Citra}

Ukuran citra merupakan bagian yang diatur di dalam persiapan sebelum melakukan proses training. Pengujian terhadap ukuran citra bertujuan untuk mengetahui ukuran citra yang paling optimal digunakan untuk melakukan verifikasi tanda tangan.

tABEL V. HASIL PENGUJIAN UKURAN CITRA

\begin{tabular}{|c|c|c|c|c|c|c|}
\hline \multirow{2}{*}{$\begin{array}{c}\text { Ukuran } \\
\text { citra }\end{array}$} & \multicolumn{2}{|c|}{$\begin{array}{c}\text { Klasifikasi } \\
\text { (acc) }\end{array}$} & \multicolumn{3}{|c|}{ Verifikasi } & \multirow{2}{*}{ Time } \\
\cline { 2 - 6 } & Train & Test & acc & sen & spe & \\
\hline $64 \times 64$ & $96 \%$ & $93 \%$ & $58 \%$ & $71 \%$ & $47 \%$ & $26 \mathrm{~s}$ \\
\hline $128 \times 128$ & $96 \%$ & $93 \%$ & $63 \%$ & $89 \%$ & $42 \%$ & $30 \mathrm{~s}$ \\
\hline $256 \times 256$ & $96 \%$ & $91 \%$ & $62 \%$ & $91 \%$ & $40 \%$ & $35 \mathrm{~s}$ \\
\hline
\end{tabular}

Pada Tabel $\mathrm{V}$ dapat diketahui bahwa akurasi testing tertinggi yaitu 93\% pada ukuran citra $64 \times 64$ dan $128 \times 128$, kemudian dihitung rata-rata ketiga jenis hasil evaluasi pada proses verifikasi untuk menentukan hasil evaluasi yang paling optimal, maka hasil evaluasi yang paling optimal yaitu pada ukuran citra $128 \times 128$ dengan akurasi testing yaitu $93 \%$, hasil accuracy sebesar $63 \%$, sensitivity sebesar $89 \%$ dan specificity sebesar $42 \%$.

\subsubsection{Pengujian Variabel Threshold}

Kemudian dilakukan pengujian terhadap variabel threshold untuk mengetahui nilai threshold terbaik sebagai tolak ukur untuk menentukan keaslian tanda tangan. Pada pengujian ini, nilai variabel threshold berada pada rentang 0,1-0,2 karena melihat dari hasil similarity antara nilai fitur citra uji dengan jumlah ratarata setiap fitur citra pada kelasnya baik data tanda tangan palsu maupun tanda tangan asli sangat mirip.

TABEL VI. HASIL PENGUJIAN VARIABEL THRESHOLD

\begin{tabular}{|c|c|c|c|}
\hline Variabel Threshold & Acc & sen & spe \\
\hline 0,1 & $38 \%$ & $10 \%$ & $62 \%$ \\
\hline 0,11 & $48 \%$ & $26 \%$ & $66 \%$ \\
\hline 0,12 & $54 \%$ & $54 \%$ & $55 \%$ \\
\hline 0,13 & $61 \%$ & $76 \%$ & $50 \%$ \\
\hline 0,14 & $62 \%$ & $85 \%$ & $45 \%$ \\
\hline 0,15 & $63 \%$ & $89 \%$ & $42 \%$ \\
\hline 0,16 & $63 \%$ & $91 \%$ & $40 \%$ \\
\hline 0,17 & $62 \%$ & $93 \%$ & $37 \%$ \\
\hline 0,18 & $61 \%$ & $92 \%$ & $37 \%$ \\
\hline 0,19 & $62 \%$ & $92 \%$ & $38 \%$ \\
\hline 0,2 & $62 \%$ & $93 \%$ & $37 \%$ \\
\hline
\end{tabular}

Pada Tabel IV ketiga jenis evaluasi hasil yaitu accuracy, sensitivity dan specificity di rata-ratakan untuk mendapatkan evaluasi hasil paling optimal, sehingga dapat diketahui bahwa nilai variabel threshold 0,15 dan 0,16 menghasilkan rata-rata akurasi yang tertinggi. Namun, pada variabel threshold dengan nilai 0,16 pembagian akurasi tidak rata karena nilai sensitivity yang sangat tinggi namun nilai specificity sangat rendah, sehingga variabel threshold yang paling optimal dipilih yaitu 0,15 dengan menghasilkan hasil evaluasi yaitu accuracy sebesar $63 \%$, sensitivity yaitu sebesar $89 \%$ dan specificity sebesar $42 \%$. Karena hasil yang diperoleh pada accuracy hanya 63\% dan specificity yang sangat rendah yaitu $42 \%$ yang berarti tanda tangan palsu banyak ditandai sebagai tanda tangan asli hal ini tentunya tidak diinginkan, sehingga perlu dicari tahu penyebab dari banyaknya kesalahan dalam menentukan tanda tangan palsu.

\subsubsection{Pengecekan Kesalahan}

Dalam mengetahui kekurangan dalam penelitian ini dilakukan beberapa pengujian. Pertama, dilakukan uji dengan menggunakan metode yang telah dipakai pada penelitian ini yaitu LBP+DCT+LVQ dimana nilai keseluruhan evaluasi hasil akan dibandingkan dengan kombinasi metode lainnya. Kedua, pengujian dengan kombinasi metode DCT+KNN yang bertujuan untuk mengetahui apakah kombinasi metode LBP dan LVQ tidak cocok digunakan untuk melakukan verifikasi tanda tangan. Ketiga, dicoba menggunakan DCT+LVQ yang bertujuan untuk mengetahui apakah ekstraksi fitur LBP yang tidak cocok digunakan untuk melakukan verifikasi tanda tangan. Keempat, dicoba menggunakan kombinasi LBP+KNN dengan tujuan untuk mengetahui apakah metode LVQ yang tidak cocok digunakan sebagai classifier. Dan terakhir, dicoba menggunakan perbandingan dataset dari 70:30 menjadi 80:20 untuk mengetahui apakah pembagian dataset yang menyebabkan hasil menjadi kurang optimal. Semua pengujian menggunakan parameter terbaik yang telah diperoleh pada skenario uji. Tabel VII menunjukkan hasil verifikasi dengan metode-metode yang telah disebutkan.

TABEL VII. HASIL VERIFIKASI

\begin{tabular}{|l|c|c|c|c|}
\hline \multicolumn{1}{|c|}{ Uji } & acc & sen & spe & Rata \\
\hline LBP+DCT+LVQ & $63 \%$ & $89 \%$ & $42 \%$ & $64,67 \%$ \\
\hline DCT+LVQ & $64 \%$ & $87 \%$ & $44 \%$ & $65 \%$ \\
\hline DCT+KNN & $59 \%$ & $94 \%$ & $31 \%$ & $61,33 \%$ \\
\hline LBP+DCT+KNN & $60 \%$ & $92 \%$ & $34 \%$ & $62 \%$ \\
\hline Dataset 80:20 & $52 \%$ & $73 \%$ & $34 \%$ & $53 \%$ \\
\hline
\end{tabular}

Berdasarkan Tabel VII dapat diketahui bahwa ratarata hasil evaluasi verifikasi tanda tangan dengan metode yang digunakan pada penelitian ini yaitu $\mathrm{LBP}+\mathrm{DCT}+\mathrm{LVQ}$ tidak jauh berbeda dengan menggunakan kombinasi metode lainnya. sehingga kesalahan bukan terletak pada metodenya. Namun, pad Tabel VII, dapat kita ketahui bahwa metode DCT+LVQ menghasilkan akurasi yang lebih optimal sehingga untuk penelitian selanjutnya, metode ini bisa dicoba untuk digunakan dalam memverifikasi tanda tangan.

Dalam pembagian dataset, perbandingan 70:30 yang sebelumnya digunakan juga sudah tepat karena bila dicoba menggunakan pembagian dataset 80:20 maka akurasi menurun hal ini disebabkan karena 
jumlah tanda tangan palsu pada data testing jauh lebih banyak yaitu 150 data sedangkan dataset tanda tangan asli hanya 90 data sehingga lebih banyak kesalahan yang dapat terjadi. Kemudian, diperhatikan nilai hasil rata-rata perhitungan similarity antara nilai fitur citra uji dengan jumlah rata-rata setiap fitur citra pada kelasnya yang dinyatakan sebagai tanda tangan asli dan palsu.

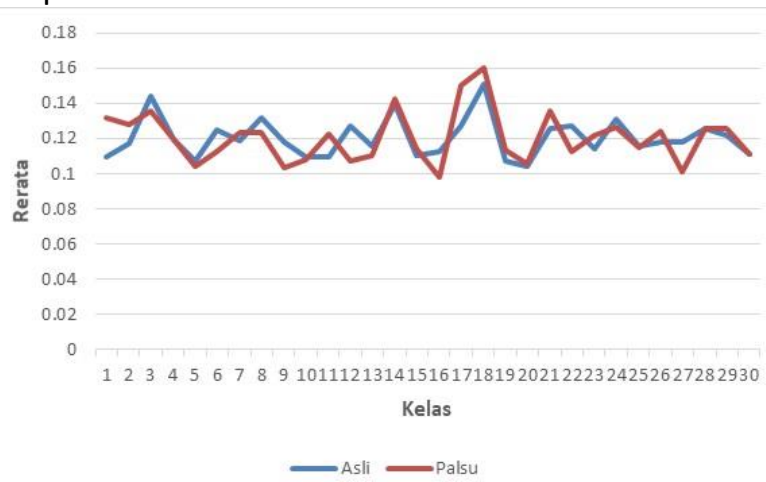

Gambar 6. Persebaran rata-rata nilai similarity tanda tangan yang dinyatakan asli dan palsu pada tiap kelas

Berdasarkan Gambar 7 dapat diketahui bahwa tanda tangan asli dan tangan palsu pada banyak kelas sangat mirip bahkan ada nilai yang tumpang tindih. Hal ini disebabkan karena aplikasi IBisPaintX yang digunakan untuk mengambil dataset merekam setiap proses pada tanda tangan yang dibuat sehingga si peniru mendapat lebih banyak informasi untuk dipelajari terutama dalam menarik garis-garis awal yang dilakukan oleh pemilik tanda tangan asli, sehingga peniru dapat membuat tanda tangan yang sangat mirip dengan aslinya.

\section{KESIMPULAN DAN SARAN}

\subsection{Kesimpulan}

Berdasarkan hasil penelitian dan pembahasan dapat ditarik beberapa kesimpulan yaitu:

1. Hasil pengujian parameter DCT terbaik yaitu pada koefisien 48 dengan akurasi training yaitu $95 \%$ dan akurasi testing yaitu $93,3 \%$.

2. Hasil pengujian parameter LBP terbaik yaitu pada $\mathrm{R}=1$ dan $\mathrm{P}=4$ dimana pada proses klasifikasi menghasilkan akurasi training yaitu $95 \%$ dan akurasi testing yaitu $93 \%$ dan pada proses verifikasi menghasilkan akurasi sebesar $57 \%$, sensitivity sebesar $71 \%$, dan specificity sebesar $46 \%$.

3. Hasil pengujian parameter LVQ terbaik yaitu pada $\mathrm{LR}=0,1$ dan Epoch=200 dimana pada proses klasifikasi menghasilkan akurasi training yaitu $96 \%$ dan akurasi testing yaitu 93\% dan pada pross verifikasi menghasilkan akurasi sebesar $58 \%$, sensitivity sebesar $72 \%$, dan specificity sebesar $47 \%$.
4. Waktu komputasi untuk ukuran citra $64 \times 64$, 128x128, dan 256x256 tidak memiliki perbedaan waktu yang signifikan. Akurasi paling optimal terdapat pada ukuran citra 128×128.

5. Variabel threshold terbaik yaitu pada variabel dengan nilai 0,15 dimana hasilnya yaitu akurasi sebesar $63 \%$, sensitivity sebesar $89 \%$, dan specificity sebesar $42 \%$.

6. Hasil verifikasi tanda tangan yang kurang optimal disebabkan oleh dataset tanda tangan asli dan palsu yang sangat mirip.

\subsection{Saran}

Ada beberapa saran yang dapat penulis berikan apabila penelitian ini akan dikembangkan kembali antara lain sebagai berikut.

1. Persiapan sebelum penelitian seperti pengambilan citra harus diperhatikan untuk mendapatkan data penelitian yang bagus.

2. Penambahan jumlah dataset untuk setiap kelas diperlukan agar classifier dapat mempelajari lebih banyak tanda tangan, sehingga akurasi menjadi lebih baik.

3. Penambahan proses segmentasi pada citra sehingga kesalahan pengenalan akibat perbedaan posisi bisa dihindari.

4. Menggunakan kombinasi metode DCT sebagai ekstraksi fitur dan LVQ sebagai classifier untuk meningkatkan akurasi verifikasi tanda tangan.

5. Menggunakan algoritma lain dalam melakukan verifikasi tanda tangan sehingga sistem dapat membedakan tanda tangan asli dan tanda tangan palsu lebih baik.

\section{UCAPAN TERIMA KASIH}

Terima kasih saya ucapkan kepada rekan-rekan di Laboratorium Sistem Cerdas serta seluruh pihak yang telah membantu dan berkontribusi dalam diskusi dan pembuatan program pada penelitian ini.

\section{Daftar Pustaka}

[1] A. Kartono and D. Alamsyah, "Verifikasi Tanda Tangan Dengan Algoritma K-Nearest Neighbor dan Ekstraksi Ciri Harris Corner," STMIK GI MDP, vol. 10, pp. 1-10, 2012.

[2] Y. D. Qur'ani and S. Rosmalinda, "Jarangan Syaraf Tiruan Learning Vector Quantization untuk Aplikasi Pengenalan Tanda Tangan," in Seminar Nasional Aplikasi Teknologi Informasi, 2010, pp. 1-5.

[3] I. Amelia, A. N. Hermana, and A. Pramana, "Verifikasi Tanda Tangan Dengan Edge Detection dan Metode 
Learning Vector Quantization," MIND J., vol. 1, no. 1, pp. 49-56, 2016.

[4] M. D. Turiyanto, D. Purwanto, and R. Dikairono, "Penerapan Teknik Pengenalan Wajah Berbasis Fitur Local Binary Pattern pada Robot Pengantar Makanan," Institut Teknologi Sepuluh November (ITS), 2014.

[5] I. G. P. S. Wijaya, K. Uchimura, and Z. Hu, "Face Recognition Based on Dominant Frequency Features and Multiresolution Metric," Int. J. Immovative Comput. Inf. Control, vol. 5, no. 1349-4198, pp. 641651, 2009.

[6] D. A. Dermawan, S. Mardi, and M. Hariadi, "Simulasi Multi Atribut di Dasarkan pada Agen untuk Kehandalan Distribusi Energi Listrik Menggunakan Metode LVQ," 2011, pp. 55-63.

[7] D. M. Wuryandari and I. Afrianto, "Perbandingan Metode Jaringan Syaraf Tiruan Backpropogation dan Learning Vector Quantization Pada Pengenalan Wajah," J. Komput. dan Inform., vol. 1, no. 1, pp. 17, 2012.

[8] J. Arifin and M. Zidny, "Verifikasi Tanda Tangan Asli Atau Palsu Berdasarkan Sifat Keacakan ( Entropi ),"

J. Inform., vol. 9, no. 1, pp. 130-135, 2017.

[9] D. Retnoningrum, A. W. Widodo, and M. A. Rahman, "Ekstraksi Ciri Pada Telapak Tangan dengan Metode Local Binary Pattern (LBP)," J. Pengemb. Teknol. Inf. dan Ilmu Komput., vol. 3, no. 3, pp. 2611-2618, 2019.

[10] A. Hidayat and Makshun, "Analisis Citra Daun Berdasarkan Fitur Local Binary Pattern dan Fitur Canny Edge Detection Menggunakan Metode Klasifikasi K-Nearest Neighboar ( K-NN )," STMIK Eresha, 2019.

[11] F. N. Achsani, R. D. Atmaja, and R. Purnamasari, "Deteksi Adanya Cacat Pada Kayu Menggunakan Metode Local Binary Pattern," e-Proceeding Eng., vol. 2, no. 1, pp. 298-305, 2015.

[12] R. V. Nahari, A. S. Editya, and R. Alfita, "Ekstraksi Fitur Daun Tembakau Berbasis Discrete Cosine Transform ( DCT )," J. Appl. Informatics Comput., vol. 4, no. 1, pp. 8-12, 2020.

[13] F. E. Alfian, I. G. P. S. Wijaya, and F. Bimantoro, "Identifikasi Iris Mata Menggunakan Metode Wavelet Daubechies dan K-Nearest Neighbor," JTIKA, vol. 2, no. 1, pp. 1-10, 2020.

[14] M. F. Permana, B. Hidayat, and S. Darana, "Identifikasi Kualitas Kesegaran Susu Sapi Melalui Pengolahan Citra Digital Menggunakan Metode
Watershad dan Klasifikasi Learning Vector Quantization (LVQ)," e-Proceeding Eng., vol. 5, no. 3, pp. 4851-4858, 2018.

[15] U. Sudibyo, E. H. Kusumaningrum, Purwanti DesiRachmawanto, and C. A. Sari, "Optimasi Algoritma Larning Vector Quantization ( LVQ) dalam Pengklasifikasikan Citra Daging Sapi dan Daging Babi," J. SIMETRIS, vol. 9, no. 1, pp. 1-10, 2018.

[16] A. A. P. B. Dwi, B. Hidayat, and J. Arif, "Identifikasi Sub-Fosil Gigi Graham pada Manusia Berbasis Pengolahan Citra Digital Menggunakan Metode Local Binary Pattern (LBP) dan Klasifikasi Learning Vector Quantization (LVQ)," in e-proceeding of Engineering, 2018, vol. 5, no. 2, pp. 2090-2098.

[17] D. A. Dharmawan, "Deteksi Kanker Serviks Otomatis Berbasis Jaringan Saraf Tiruan LVQ dan DCT," JNTETI, vol. 3, no. 4, pp. 3-6, 2014.

[18] J. Y. Sari and R. A. Saputra, "Pengenalan Finger Vein Menggunakan Local Line Binary Pattern dan Learning Vector Quantization," Ultim. Comput., vol. 9, no. 2, pp. 52-57, 2017.

[19] A. S. Syair, M. I. Sarita, and I. P. Ningrum, "Identifikasi citra tanda tangan menggunakan LBP pada smartphone berbasis android," semanTIK, vol. 5, no. 1, pp. 17-24, 2019.

[20] R. Krasmala, A. B. Purba, and U. T. Lenggana, "Kompresi Citra Dengan Menggabungkan Metode Discrete Cosine Transform ( DCT ) dan Algoritma Huffman," JOIN, vol. 2, no. 1, pp. 1-9, 2017.

[21] "Laurent. F, 1994, 'Fundamentals of Neural Networks, Architecure, Algorithms, and Application', Prentice Hall.," p. 1994, 1994.

[22] L. Fausett, Fundamental of Neural Networks, Architecture, Algorithms, and Application, 1st ed. Englewood: Pearson, 1994.

[23] S. R. Wurdianarto, S. Novianto, and U. Rosyidah, "Perbandingan Euclidean Distance dengan Canberra Distance pada Face Recognition," Techno.COM, vol. 13, no. 1, pp. 31-37, 2014

[24] M. Nishom, "Perbandingan Akurasi Euclidean Distance, Minkowski Distance, dan Manhattan Distance pada Algoritma K- Means Clustering berbasis Chi-Square," J. Inform. J. Pengenbangan IT(JPIT), vol. 04, no. 01, pp. 20-24, 2019.

[25] M. Sokolova and G. Lapalme, "A systematic analysis of performance measures for classification tasks," Inf. Process. Manag., vol. 45, no. 4, pp. 427-437, 2019. 